\title{
Facile synthesis of zirconia-coated mesoporous silica particles by hydrothermal strategy under low potential of hydrogen conditions and functionalization with dodecylphosphonic acid for high-performance liquid chromatography
}

\author{
Zhihua Song $^{\mathrm{a}, 1, *}$, Shenghong Li ${ }^{\mathrm{b}, 1}$, Yafeng Guan ${ }^{\mathrm{b}}$, Shuo Wang ${ }^{\mathrm{b}}$, Yinghao Wang ${ }^{\mathrm{a}}$, \\ Gangqiang Yang a, Xiaochen Zhang ${ }^{\mathrm{a}}$, Jinhua $\mathrm{Li}^{\mathrm{c}}$, Wenhao Song ${ }^{\mathrm{a}}$, Chuanming Zhou ${ }^{\mathrm{a}}$, \\ Lingxin Chen ${ }^{\mathrm{c}, *}$ \\ a School of Pharmacy, Collaborative Innovation Center of Advanced Drug Delivery System and Biotech Drugs in Universities of Shandong, Key Laboratory of \\ Molecular Pharmacology and Drug Evaluation (Yantai University), Ministry of Education, Yantai University, Yantai, 264005, PR China \\ ${ }^{\mathrm{b}}$ CAS Key Laboratory of Separation Sciences for Analytical Chemistry, Dalian Institute of Chemical Physics, Chinese Academy of Sciences, 457 Zhongshan \\ Road, Dalian 116023, PR China \\ ${ }^{\mathrm{C}}$ CAS Key Laboratory of Coastal Environmental Processes and Ecological Remediation, Research Center for Coastal Environmental Engineering and \\ Technology, Yantai Institute of Coastal Zone Research, Chinese Academy of Sciences, Yantai 264003, PR China
}

\section{A R T I C L E I N F O}

\section{Article history:}

Received 11 June 2019

Revised 22 October 2019

Accepted 24 October 2019

Available online 1 November 2019

\section{Keywords:}

$\mathrm{ZrO}_{2} / \mathrm{SiO}_{2}$-n synthesis

Dodecylphosphonic acid

Hydrophilic interaction chromatography

(HILIC)

Reversed-phase liquid chromatography (RPLC)

\begin{abstract}
A B S T R A C T
In this work, multilayer zirconia-coated silica $\left(\mathrm{ZrO}_{2} / \mathrm{SiO}_{2}-\mathrm{n}\right)$ microspheres were successfully produced by a straightforward hydrothermal procedure with a low concentration of $\mathrm{Zr}^{4+}(5 \mathrm{mM})$ under low potential of hydrogen $(\mathrm{pH})$ conditions $(\mathrm{pH}==2)$. The obtained $\mathrm{ZrO}_{2} / \mathrm{SiO}_{2}-\mathrm{n}$ materials exhibited favorable characteristics for high-performance liquid chromatography (HPLC) separation, including high surface area and pore volume, good pore structure, narrow particle size, and pore size distribution. In addition, the zirconia coverage in the mesopores was confirmed by soaking the material in $1 \mathrm{M} \mathrm{NaOH}$ solution, with the particles showing strong resistance to the basic solution. The obtained $\mathrm{ZrO}_{2} / \mathrm{SiO}_{2}-\mathrm{n}$ stationary phases were packed into a fused-silica capillary tubing for the separation of alkaloids in hydrophilic interaction chromatography (HILIC) mode, and a column efficiency of 47,800 plates $/ \mathrm{m}$ was obtained for berberine on a $\mathrm{ZrO}_{2} / \mathrm{SiO}_{2}-6$ micro column. The $\mathrm{ZrO}_{2} / \mathrm{SiO}_{2}-6$ microspheres were further modified by dodecylphosphonic acid $\left(\mathrm{C}_{12} \mathrm{P}-2-\mathrm{ZrO}_{2} / \mathrm{SiO}_{2}-6\right)$; the $\mathrm{C}_{12} \mathrm{P}-2-\mathrm{ZrO}_{2} / \mathrm{SiO}_{2}-6$ material showed great potential for application in reversed-phase liquid chromatography (RPLC) mode. The $\mathrm{C}_{12} \mathrm{P}-2-\mathrm{ZrO}_{2} / \mathrm{SiO}_{2}-6$ micro column showed a column efficiency of 55,000 plates $/ \mathrm{m}$ for naphthalene and 51,300 plates $/ \mathrm{m}$ for benzene.
\end{abstract}

(c) 2019 Elsevier B.V. All rights reserved.

\section{Introduction}

Over the past few decades, zirconium dioxide (zirconia), owing to its high mechanical strength and good chemical stability over a wide $\mathrm{pH}$ range of 1-14 [1,2] has triggered increasing academic interest as a sorbent for gas sensors [3], catalysis [4], sample pretreatment [5] and chromatographic separation [6]. However, zirconia microspheres show drawbacks of a low specific surface area $\left(<100 \mathrm{~m}^{2} \mathrm{~g}^{-1}\right)$ [2] and undesirable pore structure [7], which often limit their applications. To overcome such disadvantages of zirconia microspheres, mesoporous silica materials with unique physic-

\footnotetext{
* Corresponding author.

E-mail addresses: zhihuasong08@yeah.net (Z. Song), lxchen@yic.ac.cn (L. Chen).

1 The authors contributed equally.
}

ochemical properties (such as relatively high specific surface area and pore volume, narrow particle size distribution and pore size distribution, and favorable pore connectivity, as well as abundant surface hydroxyls) have been chosen as support materials [2,7-9].

Recently, nanometer-scale zirconia particles have been prepared using different kinds of $\mathrm{Zr}$ sources, which were subsequently coated onto high-surface-area micrometer-scale silica spheres $[2,7,10,11]$ to combine the high specific surface area and pore volume of mesoporous silica spheres as well as excellent chemical stability of zirconia. Dun et al. [2] prepared an anhydrous zirconia sol from zirconyl chloride octahydrate; then, a layer of surfactant as "glue" was immobilized on the surface of silica spheres, followed by the deposition of the anhydrous zirconia sol onto the porous silica spheres; thus, a kind of stationary phase with a strong resistance to basic solution was obtained by repeat- 
ing the procedure several times. It can be seen that this method clearly suffers from a tedious procedure, manipulation of complex experimental parameters, and/or time-consuming and laborious steps for immobilization. In addition, it is very difficult to improve the uniformity of the zirconia coating because of the high activity of the corresponding metal alkoxides [12] and severe aggregation of zirconia sol in the synthesis process [13]. Then, Cheralathan et al. developed a strategy based on using $\mathrm{ZrO}\left(\mathrm{NO}_{3}\right)_{2} \cdot 2 \mathrm{H}_{2} \mathrm{O}$ as a $\mathrm{Zr}$ source, and a $\mathrm{NH}_{3}$ /water vapor-induced internal hydrolysis method was adopted for the post-synthesis of a zirconia coating on the mesopore walls of SBA-15; this method is very simple, yet it is difficult to control the thickness of the zirconia shells due to the fast precipitation process in alkali conditions [14]. Therefore, the formation of a zirconia layer coating with a controllable surface morphology and surface properties on porous silica spheres in a simple and effective method remains a challenge [15]. An aqueous solution-based method offers a very simple and efficient to control the growth kinetics of the metal oxide layer by adjusting the concentration of metal ions and $\mathrm{pH}$ of the solution [16]. Lately, such a solution-based method was used by Zhang et al. for the synthesis of uniform $\mathrm{Al}_{2} \mathrm{O}_{3}$ [17] and $\mathrm{CeO}_{2}$ [18] nanoshells onto different kinds of solid substrates; a slow heterogeneous growth rather than self-nucleation into separate particles of the metal oxide was obtained by controlling the $\mathrm{pH}$ of the solution, with $\mathrm{Al}_{2}\left(\mathrm{SO}_{4}\right)_{3}$ and $\mathrm{Ce}_{2}\left(\mathrm{SO}_{4}\right)_{3}$ was used separately as the sources of the metal oxides. They obtained success in supporting metal oxide nanoshells on a solid silica surface, but did not try to make the metal oxide nanoshells inside the pores of the mesoporous silica microspheres. Based on the works of Zhang et al. [17], we proposed a strategy for the synthesis of $\mathrm{Al}_{2} \mathrm{O}_{3}$ nanoshells in the pores and on the surface of silica spheres based on decreasing the $\mathrm{Al}^{3+}$ concentration and increasing the coating cycles due to the slower mass transfer in the semi-closed mesopores under low pH conditions [19]. Afterwards, considering the good advantages of zirconia, we developed an approach to synthesize zirconia-coated silica microbeads $\left(\mathrm{ZrO}_{2} / \mathrm{SiO}_{2}\right)$ by immersing activated silica spheres into $500 \mathrm{mM} \mathrm{Zr^{4+ }}$ solution by a simple one-step method, with the obtained material modified with D-fructose 1, 6-bisphosphate (FDP) to improve the chromatographic separation property [20].

Recently, the preparation of a metal oxide coating with nanometer precision has been extensively studied, in which the surface sol-gel technique has attracted intense interest. The chemical species on a matrix surface and the molecular composition in solution are two key factors for the formation of a nanometer film coating. This approach offers the advantage of producing ultrathin conformal films with controllable thickness and composition. Based on our previous work [20], we attempt to present a new, simple, and efficient hydrothermal strategy to coat a $\mathrm{ZrO}_{2}$ layer onto the surface of bare silica several times $\left(\mathrm{ZrO}_{2} / \mathrm{SiO}_{2}-\mathrm{n}\right)$ with a lower concentration of $\mathrm{Zr}^{4+}$ under acidic solution in this work.

Then, the prepared $\mathrm{ZrO}_{2} / \mathrm{SiO}_{2}-\mathrm{n}$ particles are packed into fusedsilica capillary chromatographic columns for separation of alkaloids. In addition, dodecylphosphonic acid $\left(\mathrm{C}_{12} \mathrm{P}\right)$ are adsorbed by $\mathrm{ZrO}_{2}$-based materials via a Lewis acid-base interaction [21,22], and the obtained stationary phases are hydrophobic and applied in reversed-phase high-performance liquid chromatography (RPHPLC). In this way, the good column packing properties of silica spheres are combined with the special physicochemical properties of zirconia.

\section{Materials and methods}

\subsection{Chemicals and materials}

Silica microbeads (particle size of $5 \mu \mathrm{m}$, pore size of $100 \AA$ ) were obtained from Varian analytical instruments (USA). Zirco- nium nitrate pentahydrate was purchased from Sinopharm Chemical Reagent Co. Ltd. (Shanghai, China). Sodium hydroxide, sodium chloride and hydrochloric acid of analytical grade were bought from Kermel (Tianjin, China). Analytical-grade ethanol was obtained from Tianjin Damao Chemical Reagent Factory (Tianjin, China). Dodecylphosphonic acid $\left(\mathrm{C}_{12} \mathrm{P}\right)(97 \%$ purity) and iressa (4Quinazolinamine- $N$-(3-chloro-4-fluorophenyl)-7-methoxy-6-[3- (4morpholinyl) propoxy]) (98\% purity) were supplied by Energy (Shanghai, China). Tetrahydropalmatine, tetrandrine and lycorine were provided by DaLian Meilun Biotech Co. Ltd. (Dalian, China). Berberine chloride (98\% purity) was bought from J\&K Scientific Ltd. (Beijing, China). Uracil (98\%) was obtained from Sinopharm Chemical Reagent Co. Ltd. (Shanghai, China). Nitrobenzene, naphthalene, fluorine, benzene, toluene, ethyl benzene, n-propyl benzene, n-butyl benzene and n-pentyl benzene (98\%) were obtained from Aladdin Industrial Inc. (Shanghai, China). Methanol $\left(\mathrm{CH}_{3} \mathrm{OH}\right)$ and acetonitrile (ACN) of HPLC grade were obtained from Tedia Inc. (Fairfield, OH, U.S.A.). Wahaha purified water was used in this work (Hangzhou, China). All the chemicals were used without further purification. Fused-silica capillary tubing used in this study was purchased from Reafine Chromatography Ltd. (Hebei, China).

\subsection{Instruments and conditions}

The $\mathrm{pH}$ of the solution used in this work was measured by a $\mathrm{pH}$ meter (Leici PHS-3C, Shanghai, China) equipped with a glass electrode.

After gold sputtering for $2 \mathrm{~min}$ at $25 \mathrm{~mA}$, the morphology of the prepared materials was examined by scanning electron microscopy (SEM, SUPRA 55, ZEISS, Germany) under an energy of $5 \mathrm{kV}$. Energy dispersive spectroscopy (EDS, Oxford, UK) was used for analysis of the elemental composition of the prepared materials.

The infrared absorption spectra $\left(360-4,000 \mathrm{~cm}^{-1}\right)$ for materials ground with $\mathrm{KBr}$ were obtained using a Spectrum 100/100N (PerkinElmer, USA). Elemental analysis was carried out using a Vario EL III elemental analysis system (Elementar, Hanau, Germany). A NOVA 4000 nitrogen adsorption apparatus (QuadraSorb SI4, Florida, USA) was chosen to measure the specific surface area, pore volume, and pore size of the particles. Brunner-Emmet-Teller (BET) and Barrett-Joyner-Halenda (BJH) models were used to calculate the surface area and mesopore information from the materials, respectively.

A Malvern Zetasizer Nano-ZS90 instrument (Malvern Instruments, UK) was selected to measure the zeta potentials of the particles by suspending $1 \mathrm{mg}$ of the $\mathrm{ZrO}_{2} / \mathrm{SiO}_{2}-6$ material in $10 \mathrm{~mL}$ ammonium acetate $(20 \mathrm{mM})$ solution, and varying $\mathrm{pH}$ values $(\mathrm{pH}$ 2-11) were adjusted by sodium hydroxide and hydrochloric acid. Then, the solution was mixed thoroughly, and immediately transferred to the measurement cell.

An intrepid XSP Radial inductively coupled plasma optical emission spectroscopy (ICP-OES) (Thermo, USA) was chosen to determine the concentration of $\mathrm{Zr}$ ion: $50 \mathrm{mg}$ of the material was completely dissolved in $1 \mathrm{~mL}$ of $40 \%$ (wt.\%) HF aqueous solution, and then $1 \mathrm{~mL}$ of $68 \%$ (wt.\%) $\mathrm{HNO}_{3}$ aqueous solution was added; next, the mixture was transferred to a $100 \mathrm{~mL}$ plastic volumetric flask, diluted with water to a volume of $100 \mathrm{~mL}$, and mixed. The parameters used for operation of the ICP-OES instrument were as follows: radio frequency generator power, $1300 \mathrm{~W}$; plasma gas flow, $12 \mathrm{~L} / \mathrm{min}$; auxiliary gas flow, $0.5 \mathrm{~L} / \mathrm{min}$; nebulizer gas flow, $0.8 \mathrm{~L} / \mathrm{min}$; sample injection flow, $1.5 \mathrm{~L} / \mathrm{min}$.

\subsection{Preparation of standard solutions}

The standard solution of four kinds of common compounds, uracil $(40 \mathrm{mg} / \mathrm{L})$, nitrobenzene $\left(60 \mathrm{mg} \mathrm{L}^{-1}\right)$, naphthalene $(80 \mathrm{mg}$ $\mathrm{L}^{-1}$ ) and fluorene $\left(160 \mathrm{mg} \mathrm{L}^{-1}\right)$, was prepared by dissolving the 


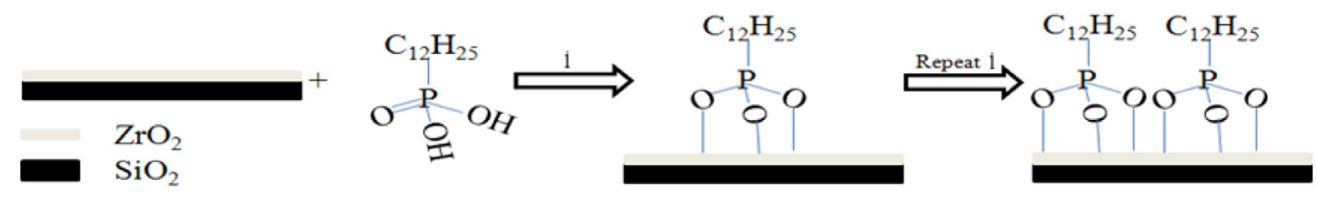

Fig. 1. Scheme for the modification of $\mathrm{ZrO}_{2} / \mathrm{SiO}_{2}-6$ microspheres by dodecylphosphonic acid twice $\left(\mathrm{C}_{12} \mathrm{P}-2-\mathrm{ZrO} \mathrm{r}_{2} / \mathrm{SiO} \mathrm{O}_{2}-6\right)$.

sample into the corresponding mobile phase. A test sample of aromatic compounds benzene $\left(1,400 \mathrm{mg} \mathrm{L}^{-1}\right)$, toluene $(1,600 \mathrm{mg}$ $\left.\mathrm{L}^{-1}\right)$, ethyl benzene $\left(1,800 \mathrm{mg} \mathrm{L}^{-1}\right)$, n-propyl benzene $(1,900 \mathrm{mg}$ $\left.\mathrm{L}^{-1}\right)$ and $\mathrm{n}$-butyl benzene $\left(1,900 \mathrm{mg} \mathrm{L}^{-1}\right)$ was prepared by dissolving the sample into a solution of the corresponding mobile phase. A mixture solution of alkaloid compounds iressa $\left(900 \mathrm{mg} \mathrm{L}^{-1}\right)$, tetrahydropalmatine ( $\left.800 \mathrm{mg} \mathrm{L}^{-1}\right)$, berberine $\left(900 \mathrm{mg} \mathrm{L}^{-1}\right)$, lycorine $\left(1,300 \mathrm{mg} \mathrm{L}^{-1}\right)$ and tetrandrine $\left(2,100 \mathrm{mg} \mathrm{L}^{-1}\right)$ was obtained by dissolving the sample into the corresponding mobile phase. The prepared standard solutions were stored in capped glass bottles and maintained at $4{ }^{\circ} \mathrm{C}$.

\subsection{Preparation of $\mathrm{ZrO}_{2} / \mathrm{SiO}_{2}$ microspheres}

The porous silica spheres (particle size of $5 \mu \mathrm{m}$, pore size of $100 \AA$ ) were first treated with $\mathrm{HNO}_{3} / \mathrm{H}_{2} \mathrm{O}(\mathrm{v} / \mathrm{v}, 1: 5)$ according to our previous work [19]. After that, $0.5 \mathrm{~g}$ dried silica particles were added to $250 \mathrm{~mL}$ aqueous solution containing $0.2 \mathrm{~mol} / \mathrm{L} \mathrm{NaCl}$ with a $\mathrm{pH}$ value of 2 followed by stirring of the mixture for $20 \mathrm{~min}$. Next, $0.54 \mathrm{~g}$ zirconium nitrate pentahydrate was rapidly dissolved into the solution, and the solution stirred during incubation at $70^{\circ} \mathrm{C}$ for $2 \mathrm{~h}$. Finally, the obtained products were collected by centrifugation, washed with water and ethanol to remove the residual reactants, and kept at $60^{\circ} \mathrm{C}$ for $8 \mathrm{~h}$ under vacuum; the obtained material was named as $\mathrm{ZrO}_{2} / \mathrm{SiO}_{2}-1$. The process was repeated several times until the desired multilayers of zirconia-coated silica microbeads $\left(\mathrm{ZrO}_{2} / \mathrm{SiO}_{2}-\mathrm{n}\right)$ were obtained.

In the experiment, $\mathrm{ZrO}_{2} / \mathrm{SiO}_{2}$-n particles, where $n==0,2,4,6$ were dried carefully. After that, the obtained $\mathrm{ZrO}_{2} / \mathrm{SiO}_{2}-\mathrm{n}$ particles were calcined in a furnace at a heating rate of $2{ }^{\circ} \mathrm{C} \mathrm{min}^{-1}$ from ambient temperature to $550^{\circ} \mathrm{C}$ and held at the same temperature for $6 \mathrm{~h}$ in the atmospheric ambient. After calcination, the obtained $\mathrm{ZrO}_{2} / \mathrm{SiO}_{2}-\mathrm{n}$ particles were used directly for HPLC separation or modification by dodecylphosphonic acid.

\subsection{Preparation of dodecylphosphonic acid modified $\mathrm{ZrO}_{2} / \mathrm{SiO}_{2}$ microspheres $\left(\mathrm{C}_{12} \mathrm{P}-2-\mathrm{ZrO}_{2} / \mathrm{SiO}_{2}-6\right)$}

The $\mathrm{C}_{12} \mathrm{P}-2-\mathrm{ZrO}_{2} / \mathrm{SiO}_{2}-6$ stationary phase was prepared by chemisorption of $\mathrm{C}_{12} \mathrm{P}$ onto the Lewis acid sites on the surface of the $\mathrm{ZrO}_{2} / \mathrm{SiO}_{2}-\mathrm{n}$ microspheres (Fig. 1) $[21,22]$. In this work, $0.3 \mathrm{~g} \mathrm{ZrO}_{2} / \mathrm{SiO}_{2}-6$ particles after calcination were placed in a $50 \mathrm{~mL}$ round-bottomed flask and suspended in $10 \mathrm{~mL}$ absolute tetrahydrofuran containing $5 \mathrm{mM}$ of $\mathrm{C}_{12}$ P. Then, the reaction was incubated for $15 \mathrm{~h}$ at $65^{\circ} \mathrm{C}$ with stirring. Afterwards, the resulting particles were filtered and washed in sequence with tetrahydrofuran and methanol. After that, the obtained $\mathrm{C}_{12} \mathrm{P}-1-\mathrm{ZrO}_{2} / \mathrm{SiO}_{2}-6$ particles were placed in a vacuum oven at $60^{\circ} \mathrm{C}$ for approximately $8 \mathrm{~h}$. In short, the synthesized $\mathrm{ZrO}_{2} / \mathrm{SiO}_{2}-6$ particles were treated twice by the procedure mentioned above. In the end, $\mathrm{C}_{12} \mathrm{P}-2-\mathrm{ZrO}_{2} / \mathrm{SiO}_{2}-6$ particles were collected and preserved in dry glass bottles for the next procedure.

\subsection{Capillary column packing}

One hundred $\mathrm{mg}$ of the stationary phases was packed into fused-silica capillary tubing $(30 \mathrm{~cm}$ length $\times 0.53 \mathrm{~mm}$ i.d.) by a drypacking method according to the procedure proposed by Guan et al. [19,20,24,25]. The parameters (dimensions, materials, power of the ultrasonic bath, etc.) used for the apparatus in this work were the same as that used in the previous work of our research group [24]. First, the dry stationary phases were discharged with a droplet of methanol, and then the packing medium was transported into micro columns by helium with a final packing pressure of $0.85 \mathrm{MPa}$.

\subsection{Micro HPLC assessment}

The micro HPLC tests were carried out with a chromatographic system equipped with Agilent 1200 quaternary pumps (Agilent Technologies, USA), a four-port rotary valve with an internal loop of $100 \mathrm{~nL}$ (Valco, TX, USA), and a Jasco CE-975 UV-VIS on-column detector (Jasco, Tokyo, Japan). To maintain a constant column pressure, a tee-piece was used as a splitter for splitting. Chromatographic data collection and analysis were carried out by a N2000 chromatographic data analysis system (Zhejiang University, China).

A solution composed of tetrahydropalmatine, iressa, lycorine, berberine and tetrandrine was injected and separated on the micro column using the mobile phase (ACN-20 mM ammonium acetate/ammonia solution with $\mathrm{pH}==10(89: 11, \mathrm{v} / \mathrm{v}))$ based on our previous work with minor modification [20]. The chromatographic separation property of the $\mathrm{C}_{12} \mathrm{P}-2-\mathrm{ZrO}_{2} / \mathrm{SiO}_{2}-6$ micro column was evaluated by using a mixture of uracil, nitrobenzene, naphthalene and fluorine; the influence of the ACN content (45\%-60\%) of the mobile phase was also investigated. Then, five kinds of alkylbenzenes were separated by the $\mathrm{C}_{12} \mathrm{P}-2-\mathrm{ZrO}_{2} / \mathrm{SiO}_{2}-6$ micro column using the same mobile phase. All the separations in this study were performed under isocratic conditions.

In this work, the flow rate of the mobile phase is $8 \mu \mathrm{L} / \mathrm{min}$, with $100 \mathrm{~nL}$ of sample injected each time; the column was evaluated at room temperature $\sim 25^{\circ} \mathrm{C}$.

\subsection{Stability testing}

\subsubsection{Stability in basic conditions}

To directly demonstrate the chemical stability of the $\mathrm{ZrO}_{2} / \mathrm{SiO}_{2}$ $\mathrm{n}$ material, $0.0100 \pm 0.0001 \mathrm{~g}$ of $\mathrm{ZrO}_{2} / \mathrm{SiO}_{2}-\mathrm{n}(n==2,4,6)$ material and bare silica particles were separately immersed into $500 \mu \mathrm{L}$ $1 \mathrm{~mol} \mathrm{~L}^{-1} \mathrm{NaOH}$ solution. The resulting solution was mixed for $3 \mathrm{~h}$ at room temperature with rotation at $60 \mathrm{rpm}$. The final $\mathrm{ZrO}_{2} / \mathrm{SiO}_{2}$ $\mathrm{n}(n==2,4,6)$ materials were rinsed with water for many times until the $\mathrm{pH}$ became neutral and collected from the solution by centrifugation at $12,000 \mathrm{rpm}$ for $3 \mathrm{~min}$. In the end, the obtained material was dried at $60^{\circ} \mathrm{C}$ under vacuum for $8 \mathrm{~h}$.

\subsubsection{Stability in carbonate buffer}

Carbonate is very aggressive for chemically bonded phases [23], and the chemical stability of three kinds of micro columns packed with bare silica, $\mathrm{ZrO}_{2} / \mathrm{SiO}_{2}-6$ and $\mathrm{C}_{12} \mathrm{P}-2-\mathrm{ZrO}_{2} / \mathrm{SiO}_{2}-6$ stationary phases were evaluated according to our previous work [20]. In this study, the packing materials were dispersed in methanol and slurry packed into micro columns ( $150 \mathrm{~mm}$ length $\times 2.1 \mathrm{~mm}$ i.d.), and then the tests were performed using an Agilent 1260 HPLC system with $80: 20(\mathrm{v} / \mathrm{v}) \mathrm{ACN}: 20 \mathrm{mM} \mathrm{NaHCO}_{3} / \mathrm{Na}_{2} \mathrm{CO}_{3}$ solution $(\mathrm{pH}==10)$ as the mobile phase. Naphthalene and berberine were selected as the 


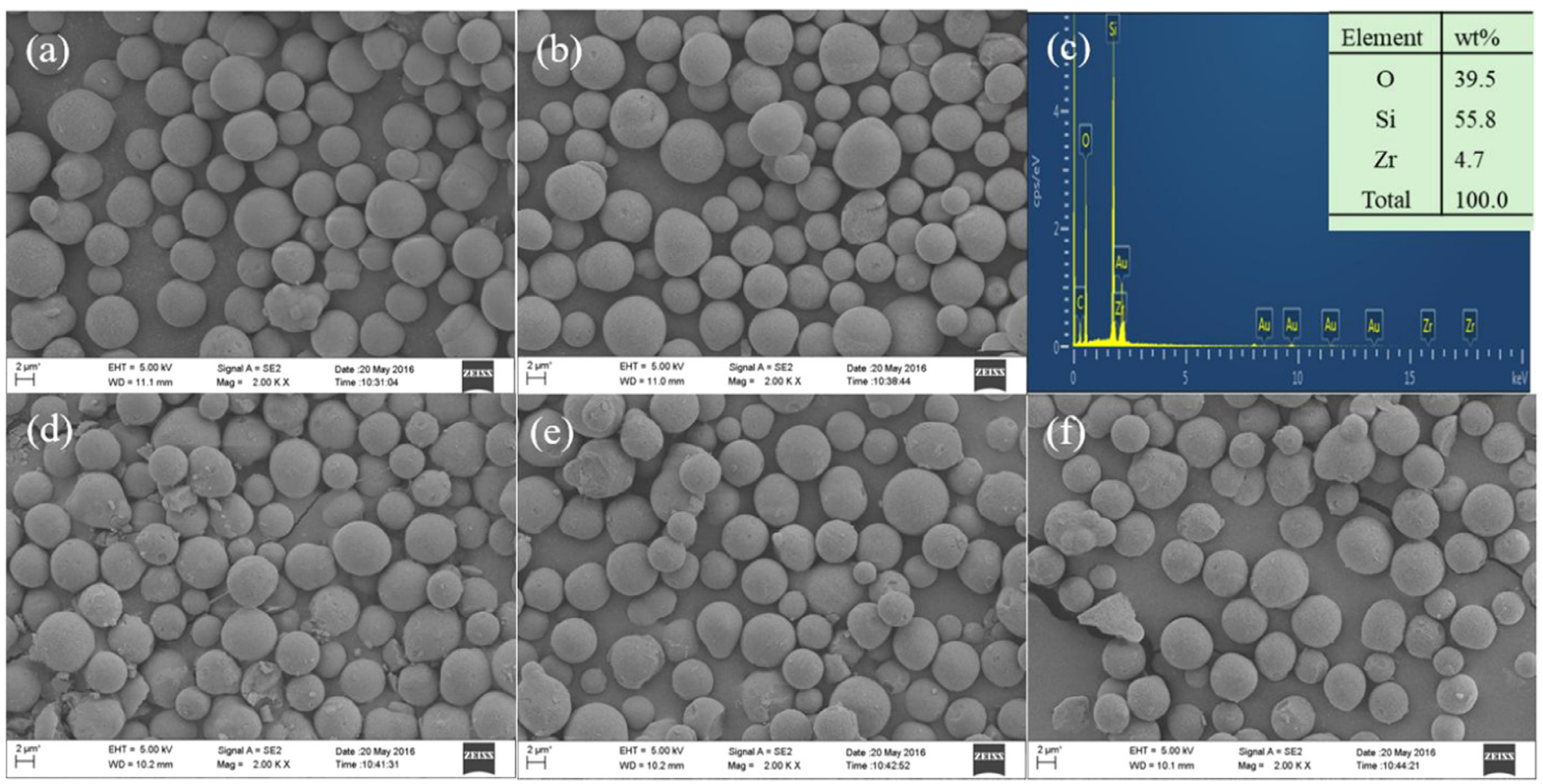

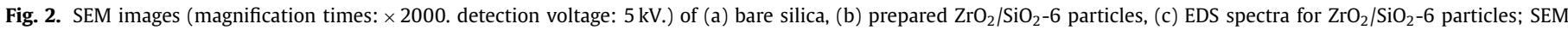
images of (d) $\mathrm{ZrO}_{2} / \mathrm{SiO}_{2}-2$, (e) $\mathrm{ZrO}_{2} / \mathrm{SiO}_{2}-4$ and (f) $\mathrm{ZrO}_{2} / \mathrm{SiO}_{2}-6$ particles after immersion for $3 \mathrm{~h}$ in $1 \mathrm{M}$ NaOH solution.

probe analytes. The parameters for the theoretical plate numbers, retention factor and symmetrical factor were investigated.

\section{Results and discussion}

In previous works, many chromatographic workers have synthesized $\mathrm{ZrO}_{2} / \mathrm{SiO}_{2}$ materials using a layer-by-layer strategy $[2,7,8]$; this strategy is time-consuming and laborious; the experimental procedures used for one coating cycle were as follows: adsorption of surfactants, dry processing, zirconia sol preparation and dry processing, with this coating cycle often repeated for several times. To make the experimental procedure easier, the one-step method for preparation of $\mathrm{ZrO}_{2} / \mathrm{SiO}_{2}$ material in the condition of a low $\mathrm{pH}$ aqueous solution and $500 \mathrm{mM} \mathrm{Zr}{ }^{4+}$ was proposed in our previous work; however, the content of $\mathrm{Zr}$ in the $\mathrm{ZrO}_{2} / \mathrm{SiO}_{2}$ was very low (2.72\%, wt.\%) [20].

Based on our previous work for the synthesis of metal oxide coated silica microbeads in acid aqueous solutions [19,20], an acidic aqueous solution of $0.2 \mathrm{M} \mathrm{NaCl}$ was adjusted to $\mathrm{pH} 2$ by concentrated hydrochloric acid. Then, a repeated coating strategy was adopted in the $\mathrm{ZrO}_{2}$ layer coating procedure to increase the content of $\mathrm{Zr}$ in $\mathrm{ZrO}_{2} / \mathrm{SiO}_{2}-\mathrm{n}$ materials. Compared with the traditional layer-by-layer strategy, this method did not need the procedures of adsorption of surfactants, dry processing and zirconia sol preparation.

The physicochemical properties, i.e., the $\mathrm{Zr}$ content, particle diameter, uniformity, specific surface area, pore structure, total pore volume and pore size, of the $\mathrm{ZrO}_{2} / \mathrm{SiO}_{2}$-n microspheres were characterized by many types of systematic characterization methods. Meanwhile, the $\mathrm{C}_{12} \mathrm{P}-2-\mathrm{ZrO}_{2} / \mathrm{SiO}_{2}-6$ microspheres were characterized by (Fourier transform infrared spectroscopy) FTIR and elemental analysis.

\subsection{Synthesis of $\mathrm{ZrO}_{2} / \mathrm{SiO}_{2}$-n microspheres}

The SEM image of the obtained materials demonstrated that the $\mathrm{ZrO}_{2} / \mathrm{SiO}_{2}-6$ particles (Fig. 2a, b) were highly spherical, smooth
Table 1

Concentration of $\mathrm{Zr}$ in bare silica and prepared $\mathrm{ZrO}_{2} / \mathrm{SiO}_{2}-\mathrm{n}(n==2,4,6)$ materials by ICP-OES.

\begin{tabular}{lll}
\hline material & $\mathrm{Zr}\left(\mathrm{mg} \mathrm{L}^{-1}\right)$ & $\mathrm{Zr}$ (wt.\%) \\
\hline Bare silica & 0 & 0 \\
$\mathrm{ZrO}_{2} / \mathrm{SiO}_{2}-2$ & 10.67 & 2.14 \\
$\mathrm{ZrO}_{2} / \mathrm{SiO}_{2}-4$ & 15.92 & 3.19 \\
$\mathrm{ZrO}_{2} / \mathrm{SiO}_{2}-6$ & 16.51 & 3.30
\end{tabular}

Three times measurement was done for each sample, and $50 \mathrm{mg}$ of the same material was used to ensure the variability of the material.

and well dispersed. There was no perceptible difference between $\mathrm{ZrO}_{2} / \mathrm{SiO}_{2}-6$ and bare silica, and no aggregated or agglomerated zirconia spheres were observed, which was significant for the final chromatographic separation procedure.

The EDS data for the $\mathrm{ZrO}_{2} / \mathrm{SiO}_{2}-\mathrm{n}(n==2,4,6)$ materials and bare silica (Fig. S1) demonstrated that the $\mathrm{Zr}$ content on the surface of the silica spheres increased with the coating cycles. However, the rate of increase in the $\mathrm{Zr}$ content on the surface of the bare silica decreased when the number of coating cycles was more than 2, with $4.7 \%$ of $\mathrm{Zr}$ found on the surface of the $\mathrm{ZrO}_{2} / \mathrm{SiO}_{2}-6$ particles (shown in Fig. 2c). A possible explanation for this is that the coated metal oxide layer can change the surface morphology of the silica spheres, and the surface becomes smooth after the stirring process [19]. Moreover, the $\mathrm{Zr}$ in the mesopores of the microspheres can be partially measured by EDS. The data from the ICP-OES measurement (shown in Table 1) (calibration curve in Fig. S2 was used for calculation) demonstrated that the $\mathrm{Zr}$ content obviously increased with increasing coating cycles, with $3.30 \%$ of $\mathrm{Zr}$ found in the $\mathrm{ZrO}_{2} / \mathrm{SiO}_{2}-6$ particles, while no $\mathrm{Zr}$ was found to exist on the surface of bare silica.

Furthermore, FTIR spectroscopy (Fig. 3) was carried out to examine the structural characteristics of as-synthesized spheres. For the $\mathrm{ZrO}_{2} / \mathrm{SiO}_{2}-6$ particles, the IR peaks near $473,806,1120 \mathrm{~cm}^{-1}$ due to the bending of the $\mathrm{Si}-\mathrm{O}-\mathrm{Si}$ group, the stretching of the Si- 


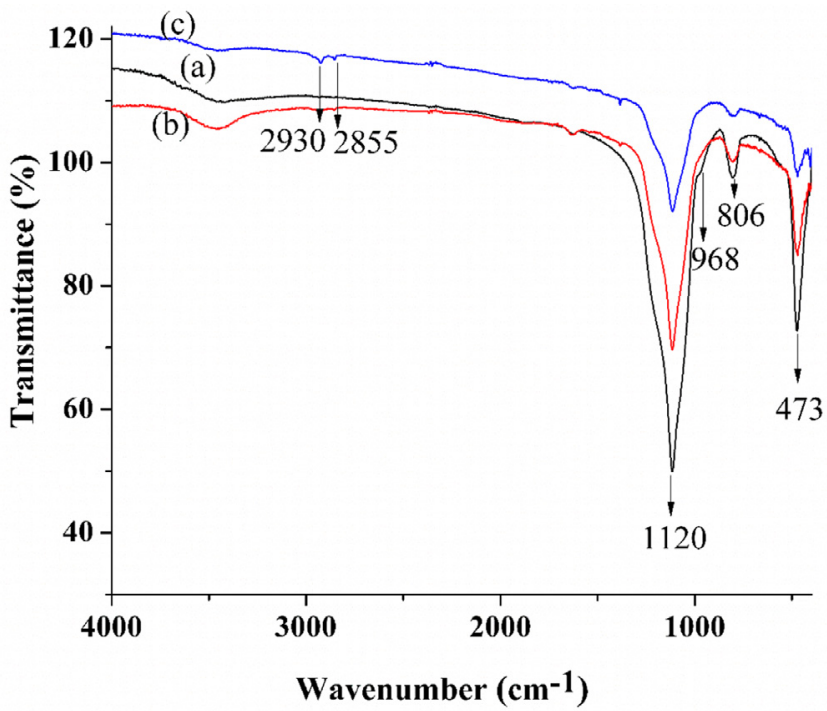

Fig. 3. FTIR spectra for (a) bare silica, (b) $\mathrm{ZrO}_{2} / \mathrm{SiO}_{2}-6$ particles and (c) $\mathrm{C}_{12} \mathrm{P}-$ $\mathrm{ZrO}_{2} / \mathrm{SiO}_{2}-6$ particles.

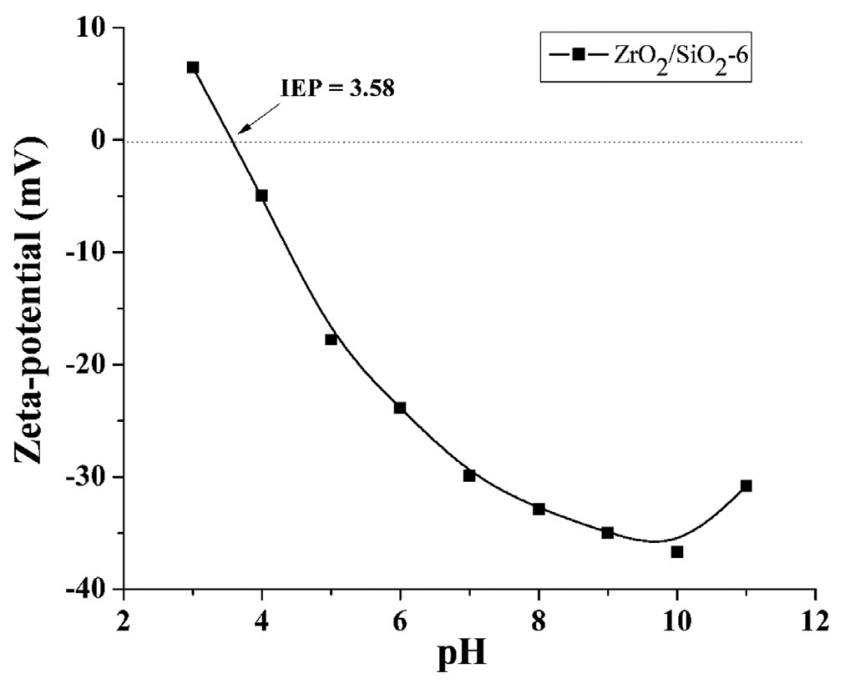

Fig. 4. Zeta-potential profiles for $\mathrm{ZrO}_{2} / \mathrm{SiO}_{2}-6$ particles according to $\mathrm{pH}$.

$\mathrm{O}-\mathrm{Si}$ group, and the stretching of the $\mathrm{Si}-\mathrm{OH}$ group, respectively, were largely decreased in intensity $[20,26]$. The formation of Si$\mathrm{O}-\mathrm{Zr}$ bonds was mostly identified by the FTIR band near $950 \mathrm{~cm}^{-1}$ shown in Fig. 3; the small peak near $968 \mathrm{~cm}^{-1}$ (the stretching of $\mathrm{Si}-\mathrm{OH})$ disappeared in the $\mathrm{ZrO}_{2} / \mathrm{SiO}_{2}-6$ particles [27]. Therefore, this result illustrated the formation of $\mathrm{Si}-\mathrm{O}-\mathrm{Zr}$ bonds at the interface between silica and the zirconium shell, which indicates the successful coating of a $\mathrm{ZrO}_{2}$ layer onto the silica microspheres.

As shown in Fig. 4, the uniformity of the zirconia grafted onto the silica particles was confirmed by measuring the zeta-potential of the $\mathrm{ZrO}_{2} / \mathrm{SiO}_{2}-6$ microspheres. It is universally known that the surface charge is positive at a low $\mathrm{pH}$ but becomes negative at a $\mathrm{pH}$ beyond the iso-electric point (IEP) [28]. It was interesting to find that the IEP of the $\mathrm{ZrO}_{2} / \mathrm{SiO}_{2}-6$ microspheres $(\mathrm{IEP}==3.58$, Fig. 4) was located between the IEP of the $\mathrm{ZrO}_{2}$ particles (IEP $==6$ 7) [29] and that of the bare silica particles (IEP=2) [30], implying that the internal and external surfaces of silica spheres were shelled with a zirconia coating layer.

The mesoporous structure of the particles was also characterized (Fig. 5); the pore volume of the $\mathrm{ZrO}_{2} / \mathrm{SiO}_{2}-\mathrm{n}$ microspheres was decreased from 0.59 to 0.54 as the coating cycles increased

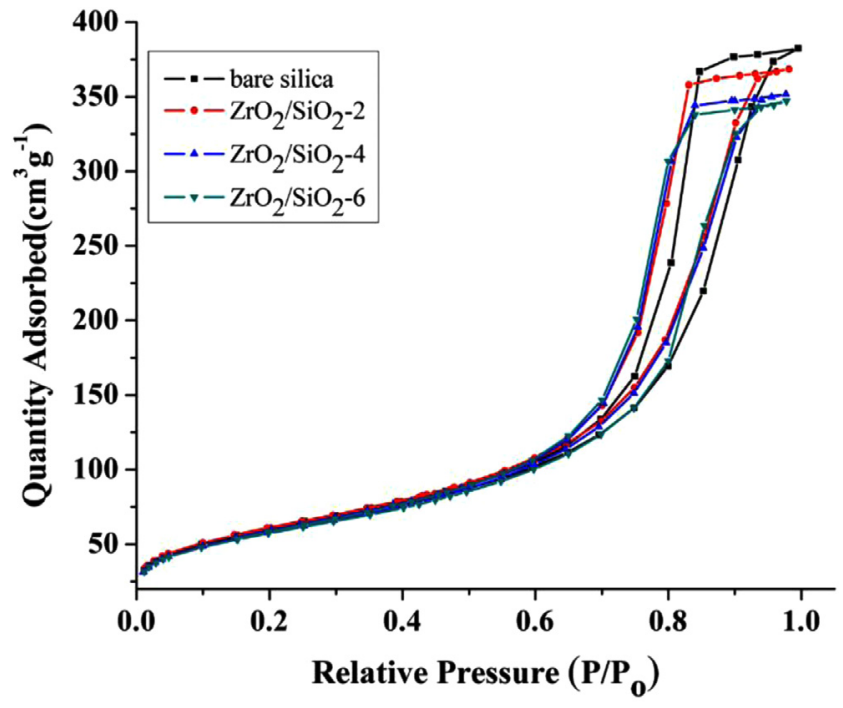

Fig. 5. $\mathrm{N}_{2}$ adsorption-desorption isotherm of bare silica and synthesized $\mathrm{ZrO}_{2} / \mathrm{SiO}_{2}$ n particles $(n=2,4,6)$.

from 0 to 6 (Table. 2). The isotherm for the materials showed that the pore structure of the $\mathrm{ZrO}_{2} / \mathrm{SiO}_{2}-\mathrm{n}$ is mesoporous; on the basis of the $\mathrm{BJH}$ model, the prepared particles had pore sizes of approximately $12 \mathrm{~nm}$ (Table 2), and the BET surface areas for all the $\mathrm{ZrO}_{2} / \mathrm{SiO}_{2}$-n microspheres were in the region of $200 \mathrm{~m}^{2} \mathrm{~g}^{-1}$, indicating that the pores of the material were not damaged by the $\mathrm{ZrO}_{2}$ layer coating process. This is efficient for liquid chromatography inside the mesopores, as the minimal pore sizes required are $>7 \mathrm{~nm}$ for liquid-phase chromatographic separation [31]. In short, the $\mathrm{ZrO}_{2} / \mathrm{SiO}_{2}-\mathrm{n}$ microspheres synthesized by the titled procedure has the advantages of a higher specific surface area and total pore volume, narrower particle size distribution and pore size distribution, better pore structure and permeability.

\subsection{Chemical modification of the $\mathrm{ZrO}_{2} / \mathrm{SiO}_{2}-6$ microspheres with dodecylphosphonic acid $\left(\mathrm{C}_{12} \mathrm{P}-2-\mathrm{ZrO}_{2} / \mathrm{SiO}_{2}-6\right)$}

He et al. synthesized n-octadecylphosphonic acid-modified magnesia-zirconia stationary phases via Lewis acid-base interactions between organophosphonate and magnesia-zirconia composite in the solvent of tetrahydrofuran [21,22]; they proposed that the activity of the hydroxyl groups on the oxide surfaces can have deleterious effects on the separation of ionizable solutes. In our study, we modified the $\mathrm{ZrO}_{2} / \mathrm{SiO}_{2}-6$ microspheres by dodecylphosphonic acid twice via the strong Lewis acid-base interactions between organophosphonate and $\mathrm{ZrO}_{2}$ layer in the solvent of tetrahydrofuran to increase the dodecyl content.

FTIR (Fig. 3c) spectroscopy for the asymmetric and symmetric $\mathrm{C}-\mathrm{H}$ stretching modes of a methylene group appearing at $2930 \mathrm{~cm}^{-1}$ and $2855 \mathrm{~cm}^{-1}$ demonstrated the successful modification of dodecylphosphonic acid on the surface of the $\mathrm{ZrO}_{2} / \mathrm{SiO}_{2}-6$ microspheres [32]. Furthermore, the elemental analysis results (Table S1) show that $4 \% \mathrm{C}$ exists on the surface of $\mathrm{C}_{12} \mathrm{P}-2-\mathrm{ZrO}_{2} / \mathrm{SiO}_{2}$ 6 , which indicated that dodecylphosphonic acid was successfully bonded onto the $\mathrm{ZrO}_{2} / \mathrm{SiO}_{2}-6$ microspheres.

\subsection{Capillary HPLC separation}

\subsubsection{Evaluation of $\mathrm{ZrO}_{2} / \mathrm{SiO}_{2}$-n stationary phases}

It has been reported that $\mathrm{ZrO}_{2} / \mathrm{SiO}_{2}-\mathrm{n}$ microspheres possess a hydrophilic interaction chromatography (HILIC) property comprising hydrogen-bonding, electrostatic and ion-exchange interactions [7]. The chromatographic separation property of $\mathrm{ZrO}_{2} / \mathrm{SiO}_{2}-\mathrm{n}$ was 
Table 2

Pore characteristic of bare silica and $\mathrm{ZrO}_{2} / \mathrm{SiO}_{2}-\mathrm{n}(n==2,4,6)$ particles.

\begin{tabular}{llll}
\hline particles & Specific surface area $\left(\mathrm{m}^{2} \mathrm{~g}^{-1}\right)$ & Mesopore width $(\mathrm{nm})$ & Specific Pore volume $\left(\mathrm{cm}^{3} \mathrm{~g}^{-1}\right)$ \\
\hline bare silica & 212.35 & 12.46 & 0.59 \\
$\mathrm{ZrO}_{2} / \mathrm{SiO}_{2}-2$ & 217.15 & 12.43 & 0.57 \\
$\mathrm{ZrO}_{2} / \mathrm{SiO}_{2}-4$ & 208.57 & 12.39 & 0.54 \\
$\mathrm{ZrO}_{2} / \mathrm{SiO}_{2}-6$ & 205.23 & 12.52 & 0.54 \\
\hline
\end{tabular}

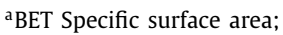

${ }^{b} \mathrm{BJH}$ adsorption pore diameter $\mathrm{Dv}(\mathrm{d})$;

'Specific surface area $\left(\mathrm{m}^{2} \mathrm{~g}^{-1}\right)$.

Table 3

Chromatographic data for separation of alkaloids on zirconia coated silica materials with different coating times $\left(\mathrm{ZrO}_{2} / \mathrm{SiO}_{2}-\mathrm{n}\right)$ under the same mobile phase condition. Mobile phase: $89 \% \mathrm{ACN}-11 \% 20 \mathrm{mM} \mathrm{NH}_{4} \mathrm{Ac}$ solution at $\mathrm{pH}$ 10. Detection: UV at $260 \mathrm{~nm}$.

\begin{tabular}{|c|c|c|c|c|c|c|c|c|c|c|c|c|}
\hline \multirow[t]{2}{*}{ Analytes } & \multicolumn{3}{|c|}{ bare silica } & \multicolumn{3}{|c|}{$\mathrm{ZrO}_{2} / \mathrm{SiO}_{2}-2$} & \multicolumn{3}{|c|}{$\mathrm{ZrO}_{2} / \mathrm{SiO}_{2}-4$} & \multicolumn{3}{|c|}{$\mathrm{ZrO}_{2} / \mathrm{SiO}_{2}-6$} \\
\hline & $\mathrm{N} / \mathrm{m}$ & $t_{F}$ & Rs & $\mathrm{N} / \mathrm{m}$ & $\mathrm{t}_{\mathrm{F}}$ & Rs & $\mathrm{N} / \mathrm{m}$ & $t_{F}$ & Rs & $\mathrm{N} / \mathrm{m}$ & $\mathrm{t}_{\mathrm{F}}$ & Rs \\
\hline tetrahydropalmatine & 13700 & 1.089 & 9.688 & 23000 & 1.219 & 7.035 & 16000 & 1.065 & 6.853 & 30000 & 1.159 & 6.784 \\
\hline iressa & 26500 & 0.953 & 7.592 & 39900 & 1.184 & & 34400 & 0.875 & 7.324 & 33600 & 1.153 & 9.796 \\
\hline lycorine & 29200 & 2.748 & & 17100 & 1.614 & 8.202 & 18700 & 1.613 & 13.188 & 41700 & 1.44 & 12.844 \\
\hline tetrandrine & - & - & & 55800 & 3.699 & 15.797 & 29300 & 2.332 & 5.391 & 39100 & 2.217 & 9.703 \\
\hline berberine & 41600 & 0.851 & & 63800 & 1.29 & 8.415 & 36700 & 1.17 & & 47800 & 1.514 & \\
\hline
\end{tabular}

$\mathrm{N} / \mathrm{m}$ : Theoretical plate number

$\mathrm{t}_{\mathrm{F}}$ : tailing factor at $5 \%$

Rs: USP resolution
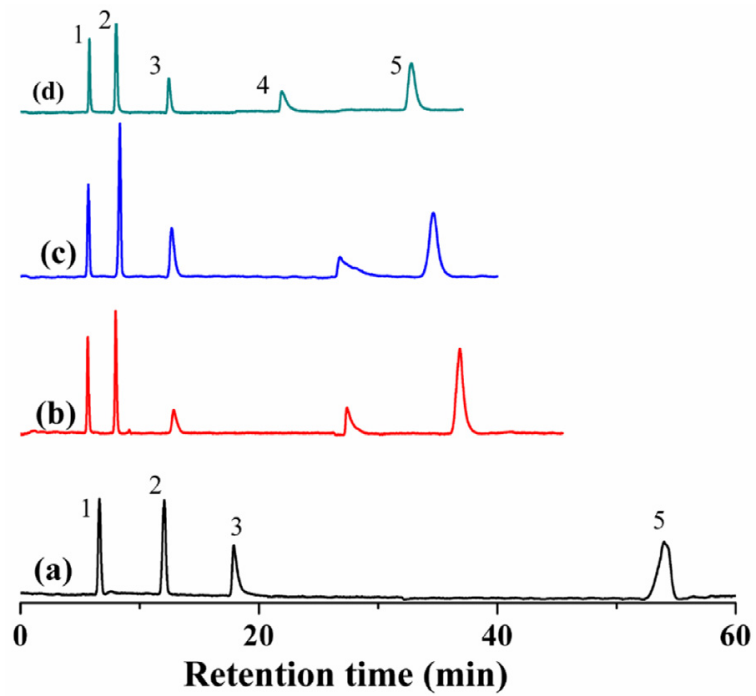

Fig. 6. Separation of (1) tetrahydropalmatine, (2) tetrahydropalmatine, (3) lycorine (4) tetrandrine, and (5) berberine on fused-silica capillary columns ( $300 \mathrm{~mm}$ length $\times 0.53 \mathrm{~mm}$ i.d.) packed with four kinds of materials (a, bare silica; b, $\mathrm{ZrO}_{2} / \mathrm{SiO}_{2}-2$ material; c, $\mathrm{ZrO}_{2} / \mathrm{SiO}_{2}-4$ material; d, $\mathrm{ZrO}_{2} / \mathrm{SiO}_{2}-6$ material) at $8 \mu \mathrm{L}$ $\mathrm{min}^{-1}$, using $\mathrm{ACN}: 20 \mathrm{mM} \mathrm{NH}_{4} \mathrm{Ac}$ aqueous solution at $\mathrm{pH} 10(89: 11, \mathrm{v} / \mathrm{v})$ at $25^{\circ} \mathrm{C}$. UV detection, $280 \mathrm{~nm}$.

evaluated and compared with commercial bare silica. Five kinds of alkaloids, tetrahydropalmatine, iressa, lycorine, tetrandrine and berberine were selected as target analytes, which are all very important in traditional Chinese medicine [33] and weakly retained in the reversed-phase liquid chromatography (RPLC) mode [20].

As shown in Fig. 6, these alkaloids are typically highly retained on bare silica and yield severely tailed peaks; tetrandrine was even completely absorbed by bare silica, while the alkaloids could be baseline separated by the stationary phase of $\mathrm{ZrO}_{2} / \mathrm{SiO}_{2}$ $\mathrm{n}$ microspheres. As shown in Table 3, on the $\mathrm{ZrO}_{2} / \mathrm{SiO}_{2}-2$ column, $\mathrm{t}_{\mathrm{F}}$ (tailing factor at $5 \%$ ) for tetrandrine was 3.699, and with the coating cycles increased to 4 and 6 , the corresponding number of $t_{F}$ decreased to 2.332 and 2.217 respectively, indicating that the $\mathrm{ZrO}_{2}$ layer coating facilitated the separation of alkaloids and the resulting particles were nearly completely modified by

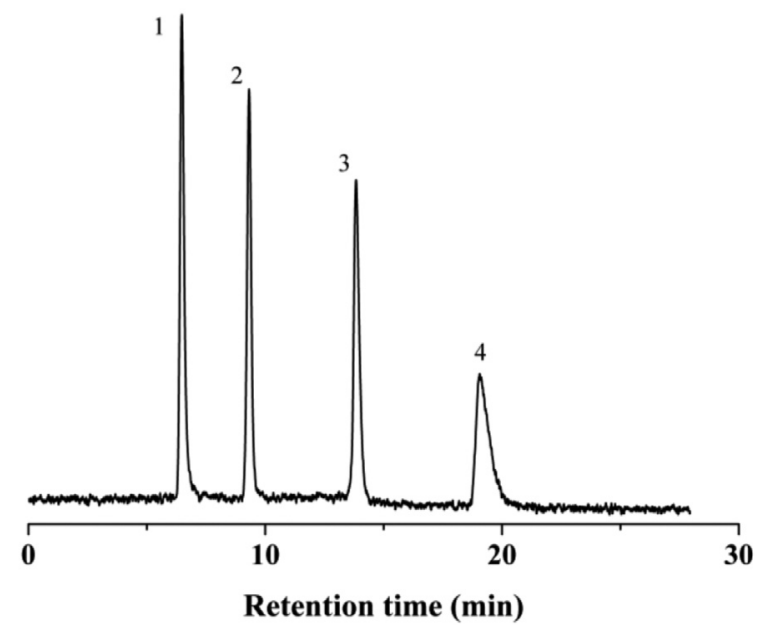

Fig. 7. Separation of (1) uracil, (2) nitrobenzene, (3) naphthalene and (4) fluorine on a fused-silica capillary column $(300 \mathrm{~mm}$ length $\times 0.53 \mathrm{~mm}$ i.d.) packed with prepared $\mathrm{C}_{12} \mathrm{P}-2-\mathrm{ZrO}_{2} / \mathrm{SiO}_{2}-6$ material at $8 \mu \mathrm{L} \mathrm{min}{ }^{-1}$, using $\mathrm{ACN}: \mathrm{H}_{2} \mathrm{O}(50: 50, \mathrm{v} / \mathrm{v})$ at $25^{\circ} \mathrm{C}$. UV detection, $254 \mathrm{~nm}$.

zirconia after 4 coating cycles; this is consistent with the result obtained by the chemical stability experiment. Moreover, the theoretical plates of the $\mathrm{ZrO}_{2} / \mathrm{SiO}_{2}-6$ column used for the separation of tetrahydropalmatine, iressa, lycorine, tetrandrine and berberine were 30,000 plates $/ \mathrm{m}, 33,600$ plates $/ \mathrm{m}, 41,700$ plates $/ \mathrm{m}$, 39,100 plates $/ \mathrm{m}, 47,800$ plates $/ \mathrm{m}$, respectively (shown in Table 3 ). The column efficiencies for the $\mathrm{ZrO}_{2} / \mathrm{SiO}_{2}-6$ column for alkaloids were much better than those reported previously [7,20]. Tetrandrine and berberine could not be separated on the commercial diol-modified silica packed micro column (shown in Fig. S3). These results evidence that the $\mathrm{ZrO}_{2}$ layer coating process described here is very meaningful for the separation of alkaloids.

3.3.2. Chromatographic separation on the $\mathrm{C}_{12} \mathrm{P}-2-\mathrm{ZrO}_{2} / \mathrm{SiO}_{2}-6$ column

To further extend the applicability of the $\mathrm{ZrO}_{2} / \mathrm{SiO}_{2}-\mathrm{n}$ microspheres, we modified the $\mathrm{ZrO}_{2} / \mathrm{SiO}_{2}-6$ microspheres with dodecylphosphonic acid based on the Lewis acid-base interaction. The optimized mobile phase was $\mathrm{ACN}-\mathrm{H}_{2} \mathrm{O}(50: 50, \mathrm{v} / \mathrm{v}$ ) (shown in Fig. S4). After that, as shown in Fig. 7, four kinds of common 


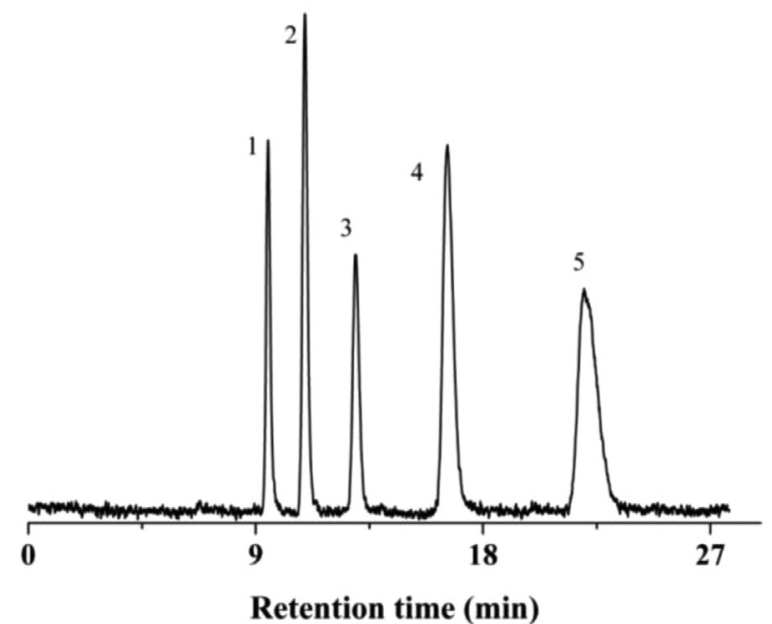

Fig. 8. Separation of (1) benzene, (2) toluene, (3) ethyl benzene, (4) n-propyl benzene and (5) n-butyl benzene on a fused-silica capillary column $(300 \mathrm{~mm}$ length $\times 0.53 \mathrm{~mm}$ i.d.) packed with prepared $\mathrm{C}_{12} \mathrm{P}-2-\mathrm{ZrO}_{2} / \mathrm{SiO}_{2}-6$ material at $8 \mu \mathrm{L}$ $\mathrm{min}^{-1}$, using $\mathrm{ACN}: \mathrm{H}_{2} \mathrm{O}(50: 50, \mathrm{v} / \mathrm{v})$ at $25^{\circ} \mathrm{C}$. UV detection, $214 \mathrm{~nm}$.

compounds including uracil, nitrobenzene, naphthalene and fluorene were chosen as standard analytes to evaluate the chromatographic separation properties of $\mathrm{C}_{12} \mathrm{P}-2-\mathrm{ZrO}_{2} / \mathrm{SiO}_{2}-6$ and commercial C18-modified silica stationary phase packed capillary columns. On the $\mathrm{C}_{12} \mathrm{P}-2-\mathrm{ZrO}_{2} / \mathrm{SiO}_{2}-6$ packed column, four kinds of probes were separated in the sequence of uracil, nitrobenzene, naphthalene and fluorene, and the corresponding column efficiency was 21,900 plates $/ \mathrm{m}, 42,900$ plates $/ \mathrm{m}, 55,000$ plates $/ \mathrm{m}$, and 19,400 plates/m, respectively. On the micro column packed with commercial C18-modified silica material, the analytes were eluted in the same order, and the column efficiency of each matching analyte was 23,300 plates $/ \mathrm{m}, 54,000$ plates $/ \mathrm{m}, 61,500$ plates $/ \mathrm{m}$, and 68,800 plates/m (shown in Fig. S5). The results demonstrated that better column efficiency was obtained on the commercial C18modified silica micro column.

To further extend the application of the $\mathrm{C}_{12} \mathrm{P}-2-\mathrm{ZrO}_{2} / \mathrm{SiO}_{2}-6$ capillary column, a mixture of aromatic compounds (shown in Fig. 8) were separated on this micro column with the mobile phase condition of $\mathrm{ACN}-\mathrm{H}_{2} \mathrm{O}(50: 50, \mathrm{v} / \mathrm{v})$; the analytes were eluted in the order of benzene, toluene, ethyl benzene, n-propyl benzene and n- butyl benzene, and the theoretical plate number of each matching aromatic compound was 51,300 plates $/ \mathrm{m}, 46,400$ plates $/ \mathrm{m}$, 41,400 plates $/ \mathrm{m}, 26,300$ plates $/ \mathrm{m}$, and 13,000 plates $/ \mathrm{m}$.

The obtained $\mathrm{C}_{12} \mathrm{P}-\mathrm{ZrO}_{2} / \mathrm{SiO}_{2}-6$ packing material combined the perfect chemical stability of $\mathrm{ZrO}_{2} / \mathrm{SiO}_{2}-6$ material with the hydrophobic and small steric hindrance properties of dodecyl. In addition, the chromatographic parameters indicated that the $\mathrm{C}_{12} \mathrm{P}-2$ $\mathrm{ZrO}_{2} / \mathrm{SiO}_{2}-6$ capillary column separated the analytes in RPLC mode. The obtained $\mathrm{C}_{12} \mathrm{P}-\mathrm{ZrO}_{2} / \mathrm{SiO}_{2}-6$ column showed better chromatographic separation property than that obtained for the octadecylbonded $\mathrm{ZrO}_{2} / \mathrm{SiO}_{2}$ columns reported by Dun et al. [2] and $\mathrm{Ge}$ et al. [8]. In short, our results demonstrate that $\mathrm{C}_{12} \mathrm{P}-2-\mathrm{ZrO}_{2} / \mathrm{SiO}_{2}-6$ stationary phase has great application potential in RPLC separation.

\subsubsection{Reproducibility and stability}

The reproducibility and stability of $\mathrm{ZrO}_{2} / \mathrm{SiO}_{2}-6$ capillary columns and $\mathrm{C}_{12} \mathrm{P}-2-\mathrm{ZrO}_{2} / \mathrm{SiO}_{2}-6$ capillary columns were evaluated by calculating the RSD of the retention time for the separation of five kinds of alkaloids (mobile phase: $89 \%$ ACN-11\% $20 \mathrm{mM}$ $\mathrm{NH}_{4} \mathrm{Ac}$ solution at $\mathrm{pH} 10$ ) and a mixture of uracil, nitrobenzene, naphthalene and fluorene (mobile phase: $50 \%$ ACN-50\% $\mathrm{H}_{2} \mathrm{O}$ solution), respectively. As shown in Table $\mathrm{S} 2$, on $\mathrm{ZrO}_{2} / \mathrm{SiO}_{2}-6$ capillary columns, the run-to-run RSD was less than $6.05 \%$, the dayto-day RSD was less than $10.73 \%$, and the column-to-column RSD was less than $6.54 \%$. In Table $\mathrm{S} 3$, on the $\mathrm{C}_{12} \mathrm{P}-2-\mathrm{ZrO}_{2} / \mathrm{SiO}_{2}-6$ capillary columns, the run-to-run, day-to-day, and column-to-column RSD was less than $3.96 \%, 3.17 \%, 8.99 \%$, respectively. These results indicate that the obtained $\mathrm{ZrO}_{2} / \mathrm{SiO}_{2}-6$ and $\mathrm{C}_{12} \mathrm{P}-2-\mathrm{ZrO}_{2} / \mathrm{SiO}_{2}-6$ stationary phases have great potential for HILIC and RPLC separation in the future.

\subsection{Stability testing}

\subsubsection{Stability in basic conditions}

Studies showed that zirconia-coated silica microspheres were significantly more resistant to basic solution compared to bare silica particles. It was easy to see that the bare silica particles were completely dissolved and that the $\mathrm{ZrO}_{2} / \mathrm{SiO}_{2}-2$ microspheres were not intact (Fig. 2d), while a small morphological change occurred on the $\mathrm{ZrO}_{2} / \mathrm{SiO}_{2}-4$ microspheres and the $\mathrm{ZrO}_{2} / \mathrm{SiO}_{2}-6 \mathrm{mi}-$ crospheres after the treatment (Fig. 2e, f). After the materials had been immersed in $1 \mathrm{M} \mathrm{NaOH}$ solution for $3 \mathrm{~h}$, the bare silica, $\mathrm{ZrO}_{2} / \mathrm{SiO}_{2}-2, \mathrm{ZrO}_{2} / \mathrm{SiO}_{2}-4$, and $\mathrm{ZrO}_{2} / \mathrm{SiO}_{2}-6$ weighed $0.0009 \mathrm{~g}$,
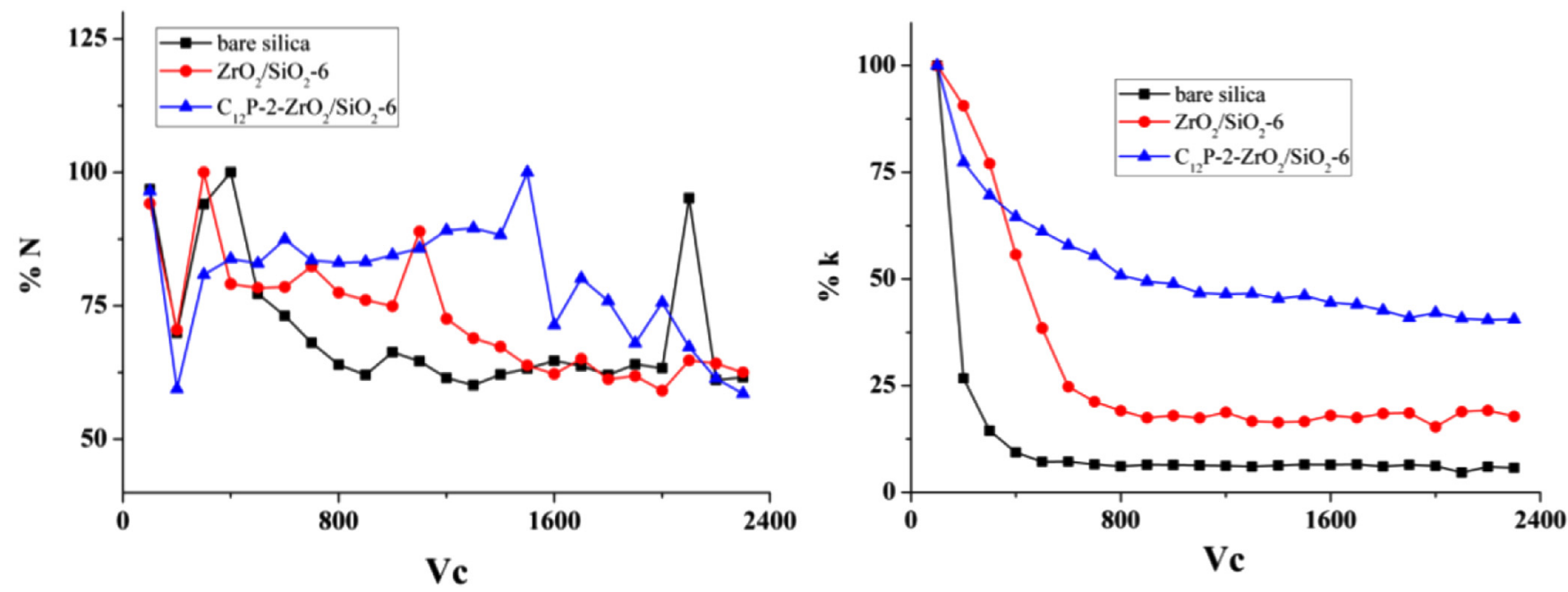

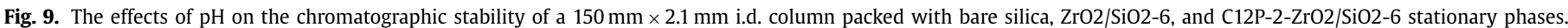

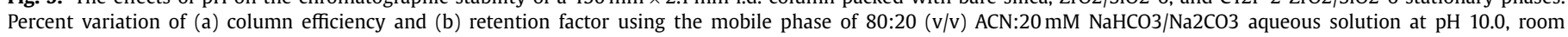
temperature $\sim 25^{\circ} \mathrm{C}$. 
$0.0038 \mathrm{~g}, 0.0049 \mathrm{~g}$, and $0.0052 \mathrm{~g}$, respectively, which was mainly due to the dissolving of the material in $\mathrm{NaOH}$ solution and the loss (approximately 5\%) in the washing procedure. The results showed that an obvious zirconia coating layer could be achieved on the internal and external surfaces of silica spheres after 4 cycles of coating, which endowed the particles some basic stability. These results are in accord with the data obtained by EDS (Fig. S1) and ICP-OES measurements (Table 1).

\subsubsection{Stability in carbonate buffer}

It has been revealed that carbonate is more aggressive than phosphate and borate for chemically bonded phases [20,23]. As shown in Fig. 9, the test carried out at room temperature $\sim 25^{\circ} \mathrm{C}$ using the mobile phase of $80: 20(\mathrm{v} / \mathrm{v}) \mathrm{ACN}: 20 \mathrm{mM} \mathrm{NaHCO} 3 / \mathrm{Na}_{2} \mathrm{CO}_{3}$ aqueous solution $(\mathrm{pH}=10)$ for 1400 column volumes caused a column efficiency loss of approximately $38 \%, 36 \%$ and $12 \%$ for the columns packed with bare silica, $\mathrm{ZrO}_{2} / \mathrm{SiO}_{2}-6$ and $\mathrm{C}_{12} \mathrm{P}-2-$ $\mathrm{ZrO}_{2} / \mathrm{SiO}_{2}-6$ materials, respectively. When the volume of the mobile phase passed thorough each column reached 2400 column volumes, the retention factor for berberine fell by $94 \%, 85 \%$ and $60 \%$ on bare silica, $\mathrm{ZrO}_{2} / \mathrm{SiO}_{2}-6$ and $\mathrm{C}_{12} \mathrm{P}-2-\mathrm{ZrO}_{2} / \mathrm{SiO}_{2}-6$ columns, respectively (shown in Fig. 9). These results demonstrate that the $\mathrm{ZrO}_{2} / \mathrm{SiO}_{2}-6$ and $\mathrm{C}_{12} \mathrm{P}-2-\mathrm{ZrO}_{2} / \mathrm{SiO}_{2}-6$ stationary phases show acceptable chemical stability in the basic mobile phase.

\section{Conclusions}

In this study, $\mathrm{ZrO}_{2} / \mathrm{SiO}_{2}-\mathrm{n}$ microspheres with good pore structure and chemical stability under alkaline conditions were successfully synthesized by a hydrothermal synthetic protocol under low $\mathrm{pH}$ conditions. The application of an acid medium solution and optimization of the number of coating cycles was very important for realizing the successful formation and attachment of zirconia onto the silica microspheres. FTIR, $\mathrm{N}_{2}$ sorption experiment, SEM and EDS analysis demonstrated that a zirconia layer was successfully coated onto the porous silica particles. From a stability experiment in basic conditions, it was easy to find that the coating quality and stability of the $\mathrm{ZrO}_{2} / \mathrm{SiO}_{2}$-n was improved as the number of coating cycles was increased from 0 to 6 . The resulting materials were further used for separation of the alkaloids in HILIC mode, with a high efficiency of 47,800 plates/m obtained for berberine, which is much higher than the efficiency obtained for a $\mathrm{ZrO}_{2} / \mathrm{SiO}_{2}$ micro column for berberine (7,100 plates/m) in our previous work [20]. Five kinds of alkaloids were separated well by a $\mathrm{ZrO}_{2} / \mathrm{SiO}_{2}-6$ micro column, while tetrandrine and berberine could not be separated by a commercial diol-modified silica micro column used in our previous study [20].

In addition, the column efficiency of the $\mathrm{C}_{12} \mathrm{P}-2-\mathrm{ZrO}_{2} / \mathrm{SiO}_{2}$ 6 micro column was lower than that obtained for a commercial C18-modified silica micro column. However, the coating of the $\mathrm{ZrO}_{2}$ layer increased the retention time stability of the $\mathrm{C}_{12} \mathrm{P}-$ $2-\mathrm{ZrO}_{2} / \mathrm{SiO}_{2}-6$ material in the basic mobile phase. The $\mathrm{C}_{12} \mathrm{P}-2-$ $\mathrm{ZrO}_{2} / \mathrm{SiO}_{2}-6$ micro column showed better separation performance than that reported previously for an octadecyl-bonded $\mathrm{ZrO}_{2} / \mathrm{SiO}_{2}$ column [2,8] and showed great potential application in RPLC. Furthermore, the prepared $\mathrm{ZrO}_{2} / \mathrm{SiO}_{2}-\mathrm{n}$ based microspheres may be a strong candidate for other potential applications, for example, sample pretreatment [10] and catalysis [14] in some cases in the future.

\section{Declaration of Competing Interest}

The authors declare that they have no known competing financial interests or personal relationships that could have appeared to influence the work reported in this paper.

\section{Acknowledgments}

The work was financially supported by project Foundation of Laboratory in Yantai university and the National Natural Science Foundation of P. R. China (grant nos. 21575159), the Department of Science and Technology of Shandong Province of China (GG201709290055), and Taishan Scholar Project Special Funding.

\section{Supplementary materials}

Supplementary material associated with this article can be found, in the online version, at doi:10.1016/j.chroma.2019.460659.

\section{References}

[1] C da Silva, C. Bottoli, C. Collins, 3-Dimensional X-ray microtomography methodology for characterization of monolithic stationary phases and columns for capillary liquid chromatography - A tutorial, Anal. Chim. Acta 991 (2017) 30-45.

[2] H. Dun, W. Zhang, Y. Wei, X. Song, Y. Li, L. Chen, Layer-by-layer self-assembly of multilayer zirconia nanoparticles on silica spheres for HPLC packings, Anal. Chem. 76 (2004) 5016-5023.

[3] F. Li, J. Zou, X. Zhang, D. Zhang, H. Jin, J. Wang, J. Jian, Discriminating hazardous gas mixture via a zirconia-based amperometric gas sensor, Ionics 24 (2018) 1451-1456.

[4] P. Kuznetsov, A. Kazbanova, L. Kuznetsova, O. Fetisova, Formation of WOx- $\mathrm{ZrO}_{2}$ isomerization catalysts from anion-modified zirconium hydroxide, Pet. Chem. 56 (2016) 629-633.

[5] L. Du, C. Chu, E. Warner, Q. Wang, Y. Hu, K. Chai, J. Cao, L. Peng, Y. Chen, J. Yang, Q. Zhang, Rapid microwave-assisted dispersive micro-solid phase extraction of mycotoxins in food using zirconia nanoparticles, J. Chromatogr. A 1561 (2018) 1-12

[6] S. Dixit, I. Lee, J. Park, Carbamoylated azithromycin incorporated zirconia hybrid monolith for enantioseparation of acidic chiral drugs using non-aqueous capillary electrochromatography, J. Chromatogr. A 1507 (2017) 132-140.

[7] Q. Wang, Z. Luo, M. Ye, Y. Wang, L. Xu, Z. Shi, L Xu, Preparation, chromatographic evaluation and application of adenosine 5 '-monophosphate modified $\mathrm{ZrO}_{2} / \mathrm{SiO}_{2}$ stationary phase in hydrophilic interaction chromatography, J. Chromatogr. A 1383 (2015) 58-69.

[8] J. Ge, X. Shi, Y. Li, L. Chen, Preparation and evaluation of octadecyl-bonded $\mathrm{ZrO}_{2} / \mathrm{SiO}_{2}$, Chromatographia 63 (2006) 25-30.

[9] C da Silva, C. Collins, Preparation and characterization of a poly(methyloctadecylsiloxane) thermally immobilized onto zirconized silica stationary phase for high-performance liquid chromatography, J. Chromatogr. A 1232 (2012) 248-256.

[10] Q. Wu, D. Wu, Y. Guan, Hybrid Titania-Zirconia nanoparticles coated adsorbent for highly selective capture of nucleosides from human urine in physiological condition, Anal. Chem. 86 (2014) 10122-10130.

[11] D. Reeder, J. Li, P. Carr, M. Flickinger, A. McCormick, Models for polybutadiene pore wall coatings in porous zirconia, J. Chromatogr. A 760 (1997) 71-79.

[12] B. Wu, C. Guo, N. Zheng, Z. Xie, G. Stucky, Nonaqueous production of nanostructured anatase with high-energy facets, J. Am. Chem. Soc. 130 (2008) 17563-17567.

[13] J. Zhang, L. Gao, Nanocomposite powders from coating with heterogeneous nucleation processing, Ceram. Int. 27 (2001) 143-147.

[14] C. Krishnan, T. Hayashi, M. Ogura, A new method for post-synthesis coating of zirconia on the mesopore walls of SBA-15 without pore blocking, Adv. Mater. 20 (2008) 2131-2136.

[15] J. Yan, X. Li, S. Cheng, Y. Ke, X. Liang, Facile synthesis of titania-zirconia monodisperse microspheres and application for phosphopeptides enrichment, Chem. Commun. (2009) 2929-2931.

[16] H. Sun, J. He, J. Wang, S. Zhang, C. Liu, T. Sritharan, S. Mhaisalkar, M. Han, D. Wang, $\mathrm{H}$. Chen, Investigating the multiple roles of polyvinylpyrrolidone for a general methodology of oxide encapsulation, J. Am. Chem. Soc. 135 (2013) 9099-9110.

[17] W. Zhang, Z. Chi, W. Mao, R. Lv, A. Cao, L. Wan, One-nanometer-precision control of $\mathrm{Al}_{2} \mathrm{O}_{3}$ nanoshells through a solution-based synthesis route, Angew. Chem. Int. Edit. 53 (2014) 12776-12780.

[18] W. Zhang, L. Yang, Z. Wu, J. Piao, A. Cao, L. Wan, Controlled formation of uniform $\mathrm{CeO}_{2}$ nanoshells in a buffer solution, Chem. Commun. 52 (2016) $1420-1423$.

[19] Z. Song, D. Wu, K. Ding, Y. Guan, Preparation of alumina nanoshell coated porous silica spheres for inorganic anions separation, J. Chromatogr. A 1433 (2016) 85-89.

[20] Z. Song, C. Duan, M. Shi, S. Li, Y. Guan, One-step preparation of zirconia coated silica microspheres and modification with D-fructose 1, 6-bisphosphate as stationary phase for hydrophilic interaction chromatography, J. Chromatogr. A 1522 (2017) 30-37.

[21] H. He, Y. Feng, L. Qu, S. Da, Z. Hu, Preparation and evaluation of n-octadecylphosphonic acid-modified magnesia-zirconia stationary phases for reversed-phase liquid chromatography, Anal. Chim. Acta 542 (2005) 268-279. 
[22] H. He, Y. Feng, S. Da, Z. Wang, An investigation on the cation-exchange and Lewis-base interactions of a n-octadecylphosphonic acid-modified magnesia-zirconia stationary phase, Anal. Chim. Acta 551 (2005) 213-221.

[23] E. Borges, C. Collins, Effects of $\mathrm{pH}$ and temperature on the chromatographic performance and stability of immobilized poly(methyloctylsiloxane) stationary phases, J. Chromatogr. A 1277 (2012) 174-180.

[24] Y. Guan, L. Zhou, Z. Shang, Dry-packed capillary columns for micro HPLC, J. High Res. Chrom. 15 (1992) 434-436.

[25] G. Crescentini, F. Bruner, F. Mangani, Y. Guan, Preparation and evaluation of dry-packed capillary columns for high performance liqiud chromatography, Anal. Chem. 60 (1988) 1659-1662.

[26] J. Silveira, S. Dib, A. Faria, New support for high-performance liquid chromatography based on silica coated with alumina particles, Anal. Sci. 30 (2014) 285-291.

[27] F. Monte, W. Larsen, J. Mackenzie, Chemical interactions promoting the $\mathrm{ZrO}_{2}$ tetragonal stabilization in $\mathrm{ZrO}_{2}-\mathrm{SiO}_{2}$ binary oxides, J. Am. Ceram. Soc. 83 (2000) 1506-1512.

[28] S. Jong Min Kim, S. Kim, K.-S. Kim, J. Kim, Woo-Sik Kim Design of $\mathrm{SiO}_{2} / \mathrm{ZrO}_{2}$ core-shell particles using the sol-gel process, Ceram. Int. 35 (2009) $1243-1247$.
[29] J. Nawrocki, M. Rigney, A. McCormick, P.W. Carr, Chemistry of zirconia and its use in chromatography, J. Chromatogr. A 657 (1993) 229-282.

[30] P. Li, C. Ohtsuki, T. Kokubo, K. Nakanishi, N. Soga, K. Degroot, The role of hydrated silica, titania, and alumina in inducing on implants, J. Biomed. Mater. Res. 28 (1994) 7-15.

[31] A. Ahmed, N. Hodgson, M. Barrow, R. Clowes, C. Robertson, A. Steiner, P. McKeown, D. Bradshaw, P. Myers, H. Zhang, Macroporous metal-organic framework microparticles with improved liquid phase separation, J. Mater. Chem. A 2 (2014) 9085-9090.

[32] K. Shiba, T. Sugiyama, T. Takei, G. Yoshikawa, Controlled growth of silica-titania hybrid functional nanoparticles through a multistep microfluidic approach, Chem. Commun. 51 (2015) 15854-15857.

[33] N. Wang, J. Zhang, Q. Li, H. Xu, G. Chen, Z. Li, D. Liu, X. Yang, Discovery of potent indoleamine 2,3-dioxygenase (IDO) inhibitor from alkaloids in Picrasma quassioides by virtual screening and in vitro evaluation, Fitoterapia 133 (2019) 137-145. 